\title{
Synergistic Effects of Doxorubicin and Cardenolid Glycosides of Calotropis Gigantea Root on Cervical Cancer Hela Cell Line
}

\section{Efek Sinergisme Doxorubisin dengan Glikosida Kardenolid dari Akar Calotropis Gigantea pada Sel Kanker Serviks Hela}

\author{
Roihatul Mutiah ${ }^{1}$, Risma Aprinda Kristanti2 ${ }^{2}$ Siti Maimunah ${ }^{3}$ \\ 1,3 Departemen Biologi Farmasi, Jurusan Farmasi Fakultas Kedokteran dan Ilmu Kesehatan Universitas Islam Negeri \\ Maulana Malik Ibrahim Malang \\ 2Program Studi Pendidikan Dokter Fakultas Kedokteran dan Ilmu Kesehatan Universitas Islam Negeri Maulana Malik \\ Ibrahim Malang
}

\begin{abstract}
Cardenolid glycosides (CGs) has been known has high anticancer activity against several types of cancers, for example, breast cancer, lung cancer, prostate cancer, melanoma, neuroblastoma, myeloma and leukemia in the in vitro and in vivo research. The aim of our study was to know the synergistic potency of CGs improving the efficacy of doxorubicin in cervical cancer. Activities from combination of doxorubicin and CGs was measured by MTT colorimetric methode. Combination Index was used as combination efficacy parameter. The results showed that the IC $C_{50}$ of CGs was $1,023 \mu \mathrm{g} / \mathrm{mL}$. CGs demonstrated selective activity in inhibiting the growth of HeLa cells by selectivity index $>3$ (241.9). Combination test for CGs and Doxorubicin showed strong synergistic effect in doses $200 \mathrm{ug} / \mathrm{mL}$ Doxorubicin and $1.79 \mathrm{ug} / \mathrm{mL}$ CGs. The synergistic effect has been shown by 10 combination doses for the doses below the IC $C_{50}$. CGs increases the efficacy of Doxorubicin for the doses below the $I C_{50}$, thus $C G s$ can be recommended as co chemotherapy in cervical cancer treatment. Keywords: Co-chemotherapy, Cardenolid glycosides (CGs), Calotropis gigantea, HeLa Cells Line
\end{abstract}

\begin{abstract}
ABSTRAK
Senyawa Glikosida Cardenolid (CGs) telah diketahui mempunyai aktivitas antikanker yang tinggi pada beberapa tipe kanker payudara, paru, prostat, melanoma,neuroblastoma, myeloma dan leukemia secara in vitro dan in vivo. Penelitian ini bertujuan untuk mengungkap potensi sinergistik senyawa CGs dalam meningkatkan efikasi doksorubisin pada kanker serviks. Aktivitas kombinasi senyawa doksorubisin dan glikosida cardenolid diukur dengan metode kolorimetri MTT. Indeks kombinasi digunakan sebagai parameter efikasi kombinasi. Hasil penelitian menunjukkan bahwa IC $C_{50}$ senyawa CGs adalah $1,023 \mu \mathrm{g} / \mathrm{mL}$. CGs menunjukkan aktivitas yang selektif dalam menghambat pertumbuhan sel kanker HeLa dengan selectivity Index $>3$ (241.9). Hasil uji kombinasi CGs dan doxorubisin menunjukkan efek sinergis kuat pada dosis doxorubisin $200 \mathrm{ug} / \mathrm{mL}$ dan CGs $1.79 \mathrm{ug} / \mathrm{mL}$. Efek sinergis ditunjukkan oleh 10 dosis kombinasi pada dosis di bawah IC ${ }_{50}$. CGs dapat meningkatkan efikasi doxorubisin pada dosis di bawah $I_{50}$. Sehingga CGs dapat direkomendasikan sebagai ko kemoterapi pada pengobatan kanker servik.

Kata kunci : Ko-kemoterapi, Glikosida cardenolid, Calotropis gigantea, HeLa Cells Line
\end{abstract}

\section{PENDAHULUAN}

Kanker servik atau kanker leher rahim merupakan penyakit kanker yang menjadi penyebab kematian kedua pada wanita setelah kanker payudara. Insidensi penyakit kanker servik mencapai 445.000 kasus pada tahun 2012 (American Cancer Society, 2015). Kanker serviks disebabkan oleh infeksi virus HPV yang ditularkan secara seksual. Beberapa usaha pengobatan

Correspondence author: Roihatul Mutiah

Email : roiha@farmasi.uin-malang.ac.id terhadap kanker telah dilakukan secara intensif yaitu dengan kemoterapi, radioterapi, dan pembedahan. Namun belum mampu secara efektif menanggulangi kanker. Kegagalan yang sering terjadi dalam pengobatan kanker tersebut, utamanya melalui kemoterapi adalah disebabkan karena rendahnya selektifitas obat-obat antikanker terhadap sel normal sehingga menimbulkan efek samping yang serius pada pasien. Selain itu kegagalan kemoterapi tersebut juga disebabkan karena resistensi sel kanker terhadap agen-agen kemoterapi. Fenomena 
resistensi tersebut membawa konsekuensi pada semakin meningkatnya dosis terapi (Tacar et al, 2013).

Strategi terapi yang tepat sangat diperlukan untuk mengatasi permasalahan tersebut. Penggunaan agen ko-kemoterapi dari bahan alam yang menghasilkan efek sinergis dengan agen kemoterapi serta dapat menghambat laju resistensi sel kanker terhadap agen kemoterapi dapat menjadi jawaban permasalahan tersebut. Penelitian ini bertujuan untuk melakukan uji kombinasi Doxorubisin dan glikosida cardenolid dari akar Calotropis gigantea terhadap sel kanker leher Rahim HeLa Cells Line.

Calotrophis gigantea merupakan tanaman obat tradisional yang tumbuh tesebar di Indonesia. Pembuktian secara ilmiah tentang aktivitas antikanker dari tanaman ini telah dilaporkan diantaranya Senyawa calotropon dari bagian akar mempunyai aktivitas sitotoksik terhadap Leukemia K562 dan gastric cancer 7901 (Wang et al., 2008). Ekstrak metanol dan fraksi kloroform dari bagian bunga mempunyai aktivitas antitumor pada mencit ascites carcinoma (Habib, Aziz and Karim, 2010). Ekstrak methanol (ME) dan fraksi chloroform akar Calotropis gigantea mampu menghambat pertumbuhan ascites carcinoma $43.90 \%$ (20 mg ME/kg) dan 57.07\% (40 mg CF/kg) (Habib and Karim, 2011) (Habib et al, 2011). Telah dilaporkan pula potensi sitotoksik senyawa cardenolid dari daun terhadap sel kanker payudara MCF-7, sel kanker kulit KB, sel kanker paru NCL-H18 (Seeka and Sutthivaiyakit, 2010), potensi sitotoksik ekstrak diklorometan dari daun terhadap sel kanker payudara MCF-7 dan MDA-MB-231, sel Hela, sel kanker kolon HT29, sel kanker ovarium SKOV-3, sel kanker hepar Hep-G2 (Wong et al., 2011).

Pada penelitian sebelumnya juga dilaporkan oleh peneliti bahwa ekstrak etanol daun Calotropis gigantea mampu menghambat pertumbuhan fibrosarcoma secara in vivo pada dosis 100 dan $150 \mathrm{mg} / \mathrm{kgbb}$ dengan mekanisme peningkatan ekspresi caspase-3 (Mutiah et al., 2016). Ekstrak akar Calotropis gigantea mempunyai aktivitas antikanker yang lebih tinggi dibanding bagian daun dan bagian bunga (Mutiah et al., 2016). Fraksi etil asetat dari bagian daun $\left(\mathrm{IC}_{50} 41.79 \mu \mathrm{g} / \mathrm{mL}\right)$ dan fraksi diklorometan $\left(\mathrm{IC}_{50} 40.57 \mu \mathrm{g} / \mathrm{mL}\right)$ mempunyai aktivitas sitotoksik yang lebih tinggi dibanding fraksi butanol (IC $_{50}$ $737.74 \mu \mathrm{g} / \mathrm{mL}$ ) dan air ( $\mathrm{IC}_{50} 8493 \mu \mathrm{g} / \mathrm{mL}$ ) (Mutiah et al., 2017). Beberapa senyawa aktif antikanker dari akar Calotropis gigantea yang telah berhasil diisolasi oleh peneliti sebelumnya yaitu calotropin, frugoside (Wang et al., 2008), afroside ,15b-hydroxycalotropin, 15b-hydroxycalactin, calactin, calotoxin, ,16a-hydroxycalactin, uscharin, , coroglaucigenin, 4'b,15b-dihydroxycalactin, 15bhydroxyuscharin, 5b-hydroxycalac-tinic acid methyl ester, calactinic acid ethyl Ester, 15bhydroxycalactinic acid ethyl ester (You et al., 2013). Senyawa aktif tersebut sebagian besar tergolong senyawa glikosida cardenolid. Cardenolide Glycosides (CGs) adalah senyawa glikosida jantung hasil isolasi fraksi etil asetat akar Calotropis gigantea yang telah melalui beberapa proses pemisahan dengan ciri noda berwarna ungu pada penyemprotan $\mathrm{H}_{2} \mathrm{SO}_{4} 10 \%$ pemanasan $105^{\circ} \mathrm{C}$ selama 5 menit. Pada penelitian ini dilakukan uji potensi senyawa glikosida cardenolid dalam meningkatkan efikasi doxorubisin pada kombinasi dosis di bawah $\mathrm{IC}_{50}$.

\section{METODOLOGI \\ Bahan Uji}

Bahan tanaman yang digunakan dalam penelitian ini adalah akar Calotropis gigantea yang diambil dari kota Malang Jawa Timur. Determinasi tanaman dilakukan di Lembaga Ilmu Pengetahuan Indonesia (LIPI) Purwodadi Jawa Timur. Spesimen tanaman di simpan di laboratorium Farmakognosi UIN Maulana Malik Ibrahim Malang.

\section{Bahan untuk ekstraksi dan isolasi}

Pelarut yang akan digunakan untuk tahap ekstraksi maserasi adalah etanol 70\% (Merck), dan etil asetat p.a (Merck), Chloroform p.a (Merck), n-heksan p.a (Merck).

\section{Bahan untuk kultur sel}

Sel kanker yang digunakan pada penelitian ini adalah sel line kanker servik HeLa. sel tersebut diperoleh dari Cancer Chemoprevention Research Centre (CCRC), Fakultas Farmasi Universitas Gadjah Mada dan dari Prof. Masasi Kawaichi, laboratorium of Gene Function in Animal, Graduate School of Biological Science, Nara Institute of Science and Technology.

Sel HeLa dalam medium Rosewell Park Memorial Institute (RPMI) ditambah dengan 10\% heat-inactvated fetal bovine serum (FBS)(PAA Labortories), $1 \% \quad \mathrm{v} / \mathrm{v}$ penicillin-streptomicin (Nacalay Tesque), dan 1,0mM L-glutamin (Nacalay Tesque). Kemudian sel dikultur dalam inkubator, pada $5 \% \mathrm{CO}_{2}, 95 \% \mathrm{O}_{2}$ suhu $37^{\circ} \mathrm{C}$.

\section{Bahan uji sitotoksik}

Dimetil sulfoksida (DMSO) digunakan untuk melarutkan isolat CGs Calotropis gigantea. Konsentrasi yang digunakan pada penelitian ini maksimal $1 \%$ dalam medium kultur. 0,025\% tripsin dalam medium kultur digunakan untuk 
memanen sel. Phosphate buffer saline (PBS) digunakan sebagai larutan penyangga pencuci. 3-(4,5-dimetiltiazole-2-il)-2,5-difeniltetrazolium.

(MTT) digunakan sebagai reagen yang bereaksi dengan enzim suksinat dehidrogenase pada sel. Doxorubisin sebagai agen kemoterapi yang akan dikombinasikan dengan CGs.

\section{Alat}

Alat utama yang diperlukan dalam penelitian ini adalah maserator, evaporator, sentrifuse ,tangki nitrogen cair, $\mathrm{CO}_{2}$-Jacketed Incubator, mikroskop fase kontras, Laminar Air Flow cabinet (Nuaire), Elisa reader.

\section{Metode Penelitian Ekstraksi}

Dimasukkan 10 bagian simplisia dengan derajat halus kedalam sebuah bejana, dituangi dengan 75 bagian cairan penyari, ditutup, biarkan selama 5 hari terlindung dari cahaya sambil sering diaduk, diserkai, diperas, ampas dicuci dengan cairan penyari secukupnya hingga diperoleh 100 bagian. Dipindahkan kedalam bejana tertutup, dibiarkan ditempat sejuk, terlindung dari cahaya selama 2 hari. Di enaptuangkan dan di saring. Filtrat yang diperoleh dikumpulkan lalu diuapkan dalam rotary evaporator pada suhu $50^{\circ} \mathrm{C}$. Ekstrak kental yang diperoleh kemudian di keringkan di desikator vakum dan selanjutnya dialiri gas N2 untuk menghilangkan semua sisa pelarut pada ekstrak (BPOM, 2010). Selanjutnya dilakukan fraksinasi terhadap ekstrak etanol dengan pelarut kloroform, etil asetat, metanol dan air.

\section{Isolasi dan identifikasi senyawa glikosida jantung}

Terhadap fraksi etil asetat (F2) dilakukan pemisahan dengan metode Vacuum Column Chromatography (VLC) menggunakan fase diam silika gel G 60 (serbuk) dan fase gerak kloroform: metanol dengan penurunan gradien $10 \%$, mulai dari kloroform 100\%, kloroform: metanol (95:5), kloroform:metanol (90:10; 80:20; 70:30; 60:40, dan 50:50). Proses pemisahan F2 dengan metode (VLC) dihasilkan 7 sub-fraksi yaitu SF1-SF7. Selanjutnya SF4 dipilih untuk dipisahkan lebih lanjut dengan dasar pada pertimbangan banyaknya rendemen yang didapatkan dari SF4 dan hasil uji sitotoksik SF1-SF7 yang menunjukkan bahwa SF4 bersifat aktif terhdap sel kanker dengan $\mathrm{IC}_{50}(14.31 \mu \mathrm{g} / \mathrm{mL})($ Mutiah, 2017). Selanjutnya terhadap sub fraksi SF4 dilakukan pemisahan menggunakan kromatografi kolom terbuka dengan fase diam silika gel 60 dan fase gerak gradien pelarut, yaitu campuran heksan dan etil asetat $4: 1$, selanjutnya campuran etil asetat dan kloroform 9:1; kemudian dilanjutkan dengan campuran kloroform dan metanol 1:1 dan terakhir menggunakan methanol. Dari proses pemisahan ini dihasilkan 5 sub fraksi yaitu SF4.1, SF4.2, SF4.3, SF 4., SF 4.5. Terhadap SF 4.5 dilakukan isolasi dan identifikasi senyawa glikosida jantung dengan metode KLT preparative dengan eluen chloroform:methanol (9:1), penampak noda $\mathrm{H}_{2} \mathrm{SO}_{4} 10 \%$. Noda warna ungu menunjukkan positif Glikosida Cardenolid. Isolat yang diperoleh disebut isolat CGs.

\section{Identifikasi senyawa Glikosida Jantung dengan metode UPLC/MS}

Identifikasi isolat CGs menggunakan alat UP-LCMS/MS tipe alat ACQUITY UPLC I-Class (Waters) dengan detektor diode-array detector (DAD) 2996 (waters); kolom : Sunfire C18, p $50 \mathrm{~mm}$, diameter $2 \mathrm{~mm}$, ukuran partikel um (waters). Fase gerak: gradient asetonitril; air; asam formiat, flow rate $1 \mathrm{~mL} / \mathrm{min}$, volum injeksi 10uL. MS system Xevo G2-S Qtof (waters), analyser: TOF dengan electrosprayer modus positif dan negative (ES+) (ES-); alir gas 794L/min.

\section{Uji aktivitas antikanker dengan metode MTT}

Suspensi sel kanker servix (HeLa cell Line) sebanyak $100 \mu \mathrm{L}$ dengan kepadatan $3 \times 10^{4}$ sel $/ 100 \mu \mathrm{L}$ media didistribusikan ke dalam sumuran- sumuran pada 96-well plate dan diinkubasikan selama 24 jam. Setelah diinkubasi, ke dalam sumuran dimasukkan $100 \mu \mathrm{L}$ larutan uji pada berbagai seri konsentrasi. Larutan uji yang digunakan adalah ekstrak crude glikosida jantung dan kombinasi dengan doxorubisin. Sebagai kontrol positif ditambahkan $100 \mu \mathrm{L}$ medium kultur, kemudian $100 \mu \mathrm{L}$ doxorubisin, pada berbagai seri konsentrasi ke dalam sumuran yang telah berisi $100 \mu \mathrm{L}$ suspensi sel kanker HeLa. Sebagai kontrol sel ditambahkan $100 \mu \mathrm{L}$ medium kultur ke dalam sumuran yang berisi $100 \mu \mathrm{L}$ suspensi sel dan sebagai kontrol pelarut ditambahkan $100 \mu \mathrm{L}$ DMSO ke dalam sumuran yang berisi $100 \mu \mathrm{L}$ medium kultur dan $100 \mu \mathrm{L}$ suspensi sel dengan delusi yang sesuai dengan delusi konsentrasi larutan uji, kemudian diinkubasi selama 24 jam dalam inkubator dengan aliran 5\% $\mathrm{CO}_{2}$ dan 95\% $\mathrm{O}_{2}$. Pada akhir inkubasi, media kultur dibuang lalu ditambahkan $10 \mu \mathrm{L}$ larutan MTT (5 mg/mL PBS), dan medium diganti dengan $190 \mu \mathrm{L}$ medium RPMI 1640 komplit. Kemudian sel diinkubasi selama 3-4 jam. Reaksi MTT dihentikan dengan penambahan reagen stopper SDS $(100 \mu \mathrm{L})$. Microplate kemudian dibungkus dengan tissue dan diinkubasi selama 1 malam pada suhu kamar dan ruangan gelap. Sel 
yang hidup bereaksi dengan MTT membentuk warna ungu. Hasil pengujian dibaca dengan ELISA reader pada panjang gelombang $595 \mathrm{~nm}$ (CCRC UGM dalam Mutiah, 2014).

\section{Analisis Data}

Data yang diperoleh berupa absorbansi masing-masing sumuran dikonversi ke dalam persen sel hidup:

Prosentase (\%)sel hidup

$=\frac{(\text { abs. perlakuan }- \text { abs. kontrol media })}{(\text { abs. kontrol sel }- \text { abs. kontrol media })} \times 100 \%$ Keterangan: Abs: absorbansi

Prosentase sel hidup dihitung untuk memperoleh nilai $\mathrm{IC}_{50}$ yaitu konsentrasi yang menyebabkan penghambatan pertumbuhan sebanyak 50\% dari populasi sel sehingga dapat diketahui potensi sitotoksiknya. Nilai $\mathrm{IC}_{50}$ ditentukan dengan analisis probit (Statistic Product and Service Solution (SPSS) 16.0 for windows). Sitotoksisitas kombinasi ditetapkan dengan menghitung indeks interaksi antara agen kemoterapi dengan isolat CGs, menggunakan persamaan:

Combination Index/CI=(D)1/(Dx)1 + (D)2/(Dx)2

Dimana D1 dan D2 adalah konsentrasi sampel yang digunakan dalam perlakuan kombinasi. (Dx)1 dan (Dx)2 adalah konsentrasi tunggal yang dapat menghasilkan efek sebesar yang diberikan perlakuan kombinasi (Reynold dan Maurer, 2005). Angka CI atau Combination Index yang diperoleh diinterpretasikan sebagai berikut:,< 0.1 sinergis sangat kuat, 0.1-0.3 sinergis kuat, 0.3-0.7 sinergis, 0.7-0.9 sinergis ringansedang, 0.9-1.1 antagonis ringan-sedang, 1.45-.3 antagonis, > antagonis kuat-sangat kuat.

\section{HASIL DAN PEMBAHASAN}

Penelitian ini bertujuan untuk mengungkap efek antikanker kombinasi doxorubisin dan dan isolat Cardenolide Glycosides (CGs) terhadap sel kanker servik HeLa. Kombinasi senyawa CGs dan doxorubisin diharapkan mempunyai efek sinergisme yang lebih besar dari penggunaan monoterapi. Dosis yang digunakan adalah dosis dibawah $\mathrm{IC}_{50}$ sehingga penurunan dosis ini diharapkan juga dapat menurunkan efek samping agen kemoterapi khususnya doxorubisin. Pada penelitian sebelumnya menunjukkan bahwa kombinasi ekstrak Calotropis gigantea dengan 5-Fluorourasil (dosis 62,5 $\mathrm{g} / \mathrm{mL}, 125 \mu \mathrm{g} / \mathrm{mL}$ ) memberikan efek sinergisme terhadap sel kanker kolon WiDr dengan Combination Indexs 0.02
(Mutiah dkk, 2016). Berdasar pada penelitian tersebut peneliti ingin mengungkap efek sinergisme kombinasi isolat CGs dengan doxorubisin terhadap sel kanker HeLa. Pada uji sitotoksik CGs terhadap sel kanker Hela didapatkan $\mathrm{IC}_{50}$ pada konsentrasi $1.023 \mu \mathrm{g} / \mathrm{ml}$ (Tabel I).

\section{Identifikasi isolat Isolat CGs menggunakan metode UP-LCMS/MS}

Berdasarkan data kromatogram, pada waktu retensi 1.27 menit merupakan puncak tunggal dengan luas area yang dominan. Berdasarkan analisis UPLCMS/MS maka dapat diketahui bahwa senyawa yang teridentifikasi adalah senyawa dengan berat molekul 577.8150 yang terfragmentasi $\mathrm{m} / \mathrm{z} \quad 402.8871 ; \mathrm{m} / \mathrm{z}$ 301.9556; $\mathrm{m} / \mathrm{z} 144.9870$ yang identik dengan senyawa oleandrin

\section{Uji aktivitas antikanker CGs terhadap sel HeLa}

Terhadap isolat CGs dilakukan pengujian aktivitas antikanker (Tabel I) secara in vitro pada sel kanker HeLa dengan metode MTT assay.

Berdasarkan data pada tabel tersebut di atas menunjukkan bahwa nilai $\mathrm{IC}_{50}$ dari isolat CGs memiliki rentang nilai $\mathrm{IC}_{50}$ dibawah nilai yang disebutkan oleh NCI. Dengan demikian dapat dinyatakan bahwa isolat CGs efektif sebagai antikanker. Gambaran morfologi sel kanker Hela akibat perlakuan isolat CGs disajikan pada gambar 4 di bawah ini.

Gambar 4. Perbandingan efek penghambatan pertumbuhan sel (aktifitas antikanker) karena perlakuan isolat CGs dengan berbagai konsentrasi pada sel kanker Hela dengan metode reduksi MTT. Sel sebanyak $10^{4}$ sel/sumuran ditanam dalam 96 well plate, diinkubasi selama 24 jam dalam media RPMI komplit. Morfologi sel diamati di bawah mikroskop fase kontras dengan perbesaran 200x, sel hidup ditunjukkan oleh anak panah (a). Terjadi perubahan morfologi pada perlakuan isolat CGs yaitu berupa blebbing (b), membesar (d,c).

Berdasarkan pada gambar 4 menunjukkan bahwa perlakuan isolat CGs menyebabkan perubahan morfologi pada sel Hela yang linier dengan peningkatan konsentrasi uji. Sel Hela pada kontrol tampak berbentuk oval dengan sitosol jernih dan melekat pada dasar Tissue Culture Dish (TCD). Setelah perlakuan dosis 5,37ug/ml; 3,58 $\mathrm{ug} / \mathrm{ml} ; 1,79 \mathrm{ug} / \mathrm{ml}$ sebagian sel tampak membulat dan terlepas dari TCD. Sel terlihat keruh dan kompak, tampak seperti mengalami kondensasi dan pengkerutan inti serta granulasi pada sitosol. 


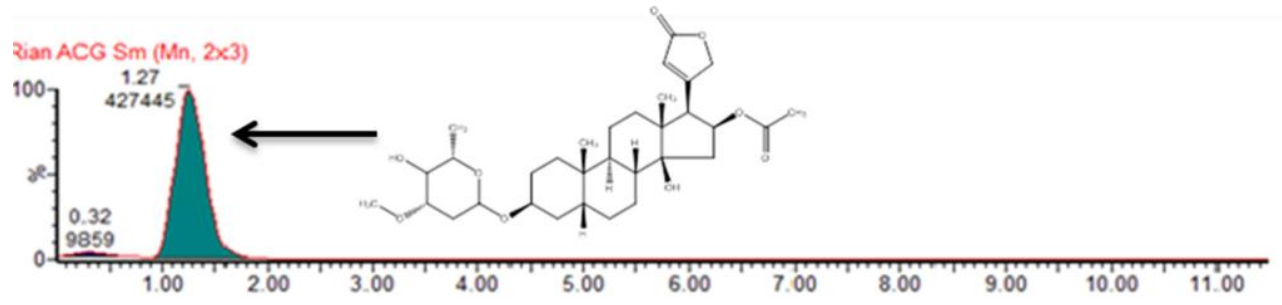

Gambar 1. Kromatogram UPLCMS/MS CGs (oleandrin) dengan fase diam sunfire C18 2x $50 \mathrm{~mm}$ column, dan fase gerak gradient Asetonitril: $\mathrm{H}_{2} \mathrm{O}$ ), flow rate $1 \mathrm{ml} / \mathrm{min}$. Tanda panah menunjukkan puncak tunggal isolat CGs yang keluar pada waktu retensi 1.27 menit.

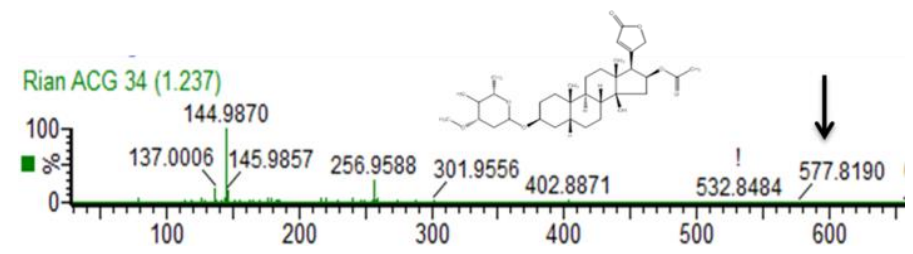

Gambar 2. Spektra massa CGs (oleandrin) pada waktu retensi 1.27 menunjukkan m/z 577.8190 yang terfragmentasi pada m/z 402.8871; m/z 301.9556; m/z144.9870.

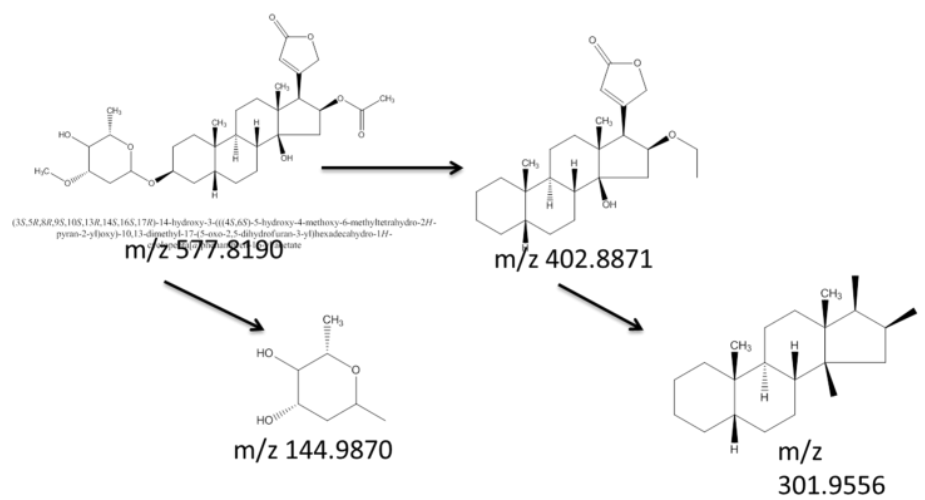

Gambar 3. Gambar ilustrasi fragmentasi senyawa oleandrin

\section{Uji aktifitas antikanker isolat CGs (glikosida cardenolid) terhadap sel Vero}

Untuk mengetahui tingkat selektifitas senyawa dalam menghambat pertumbuhan sel kanker HeLa maka terhadap isolat CGs (glikosida cardenolid) dilakukan pengujian aktivitas antikanker (Tabel II) secara in vitro pada sel normal Vero dengan metode MTT assay.

Berdasarkan data pada tabel tersebut di atas menunjukkan bahwa nilai $\mathrm{IC}_{50}$ dari isolat CGs terhadap sel Vero adalah sebesar 247,48 ug/ml. Untuk mengetahui tingkat selektifitas senyawa maka dilakukan perhitungan selektifitas (Tabel III).

Berdasarkan tabel tersebut di atas dapat diketahui bahwa nilai SI isolat CGs adalah > 3 . Ekstrak dikatakan selektif apabila nilai selektifitas indeks lebih besar dari 3 (Prayong et al, 2008). Dengan demikian dapat dinyatakan bahwa isolat CGs selektif dalam membunuh sel kanker hela.

\section{Uji aktifitas ko-kemoterapi isolat CGs dengan doxorubisin}

Terhadap isolat CGs dilakukan uji kombinasi dengan obat kemoterapi doxorubisin. Uji ini bertujuan untuk mengetahui efek sinergisme antara senyawa CGs (oleandrin) dengan doxorubisin. Hasil uji aktivitas kombinasi tersebut dalam menghambat pertumbuhan sel kanker HeLa disajikan pada tabel di bawah ini:

Hasil uji kombinasi ini menunjukkan bahwa perlakuan kombinasi isolat CGs dan doxorubisin menghasilkan efek yang lebih besar dibandingkan dengan efek senyawa tunggal dengan konsentrasi yang lebih tinggi. Hal ini tentu saja menjadi harapan bagi terapi kanker yang mempunyai masalah rumit terkait dengan resistensi dan efek samping sejalan dengan peningkatan dosis.

Gambar 5. pengaruh perlakuan kombinasi isolat CGs dan DOX terhadap pertumbuhan sel kanker HeLa. Perlakuan kombinasi CGs dan DOX 
Tabel I. Rata-rata persen viabilitas sel dan nilai $\mathrm{IC}_{50}$ isolat $\mathrm{CGs}$ pada sel kanker servik Hela

\begin{tabular}{|c|c|c|c|c|c|c|c|c|}
\hline \multirow{2}{*}{$\begin{array}{l}\mathbf{N} \\
\mathbf{0}\end{array}$} & \multirow[t]{2}{*}{ Isolat } & \multicolumn{6}{|c|}{$\begin{array}{l}\text { Rata-rata \% viabilitas sel Hela } \pm \text { SD* } \\
\text { Pada konsentrasi uji }(\mu \mathrm{g} / \mathrm{mL})\end{array}$} & \multirow{2}{*}{$\begin{array}{c}\mathrm{IC}_{50} \\
(\mu \mathrm{g} / \mathrm{mL}) \pm \\
\mathrm{SD}^{*}\end{array}$} \\
\hline & & 0.4475 & 0.895 & 1.79 & 3.58 & 5.37 & 7.15 & \\
\hline 1 & $\begin{array}{l}\text { Isolat } \\
\text { CGs45 }\end{array}$ & $\begin{array}{c}57.05 \pm 0.6 \\
9\end{array}$ & $\begin{array}{c}48.48 \pm 4.9 \\
7\end{array}$ & $\begin{array}{c}47.19 \pm 0.7 \\
3\end{array}$ & $\begin{array}{l}38.32 \pm 0.0 \\
2\end{array}$ & $\begin{array}{c}43.2 \pm 0.1 \\
0\end{array}$ & $\begin{array}{l}35.75 \pm 0.1 \\
4\end{array}$ & $\begin{array}{c}1.023 \pm 0.03 \\
5\end{array}$ \\
\hline
\end{tabular}

*Nilai rata-rata dan Simpangan Deviasi dengan 3 kali replikasi
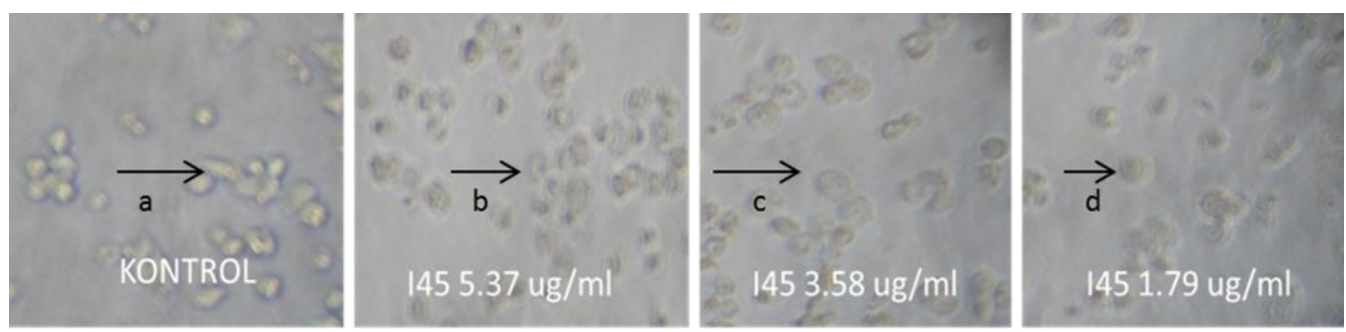

Gambar 4. Perbandingan efek penghambatan pertumbuhan sel (aktifitas antikanker) karena perlakuan isolat CGs dengan berbagai konsentrasi pada sel kanker Hela dengan metode reduksi MTT. Sel sebanyak $10^{4}$ sel/sumuran ditanam dalam 96 well plate, diinkubasi selama 24 jam dalam media RPMI komplit. Morfologi sel diamati di bawah mikroskop fase kontras dengan perbesaran 200x, sel hidup ditunjukkan oleh anak panah (a). Terjadi perubahan morfologi pada perlakuan isolat CGs yaitu berupa blebbing (b), membesar $(\mathrm{d}, \mathrm{c})$.

Tabel II. Rata-rata persen viabilitas sel dan nilai IC $_{50}$ isolat CGs pada sel normal Vero

\begin{tabular}{|c|c|c|c|c|c|c|c|c|}
\hline \multirow{2}{*}{ Isolat } & \multicolumn{7}{|c|}{ Rata-rata \% viabilitas sel Vero \pm SD $^{*}$ pada konsentrasi uji $(\mu \mathrm{g} / \mathrm{mL})$} & \multirow{2}{*}{$\begin{array}{c}\mathrm{IC}_{50} \\
(\mu \mathrm{g} / \mathrm{mL}) \pm \\
\mathrm{SD}^{*}\end{array}$} \\
\hline & 15.625 & 31.25 & 62.5 & 125 & 250 & 500 & 1000 & \\
\hline Isolat & $82.50 \pm$ & $63.52 \pm$ & $69.03 \pm$ & $69.03 \pm$ & $68.15 \pm$ & $47.13 \pm$ & $11.28 \pm$ & $247.48 \pm$ \\
\hline CGs45 & 0.65 & 1.23 & 0.89 & 0.56 & 1.67 & 2.34 & 2.36 & 0.56 \\
\hline
\end{tabular}

*Nilai rata-rata dan Simpangan Deviasi dengan 3 kali replikasi

Tabel III. SI (selectivity Index) isolat CGS terhadap sel Kanker Hela

\begin{tabular}{cccccc}
\hline No & bahan & $\begin{array}{c}\text { Hela IC } \\
(\mu \mathrm{g} / \mathrm{mL})\end{array}$ & $\begin{array}{c}\text { Vero } \\
\text { IC }_{50} \\
(\mu \mathrm{g} / \mathrm{mL})\end{array}$ & SI (selectivity Index) & Keterangan \\
\hline & 1 Isolat 4.5 & 1.023 & 247.48 & 241.9 & Selektif* $^{2}$ \\
\hline
\end{tabular}

*Nilai rata-rata dan Simpangan Deviasi dengan 3 kali replikasi

Tabel IV. aktivitas antikanker kombinasi isolat CGs dan doxorubisin terhadap Viabilitas sel HeLa

\begin{tabular}{ccccc}
\hline \multicolumn{5}{c}{ Viabilitas sel \% $\mathbf{~ S D *}$} \\
\hline $\begin{array}{c}\text { CGs } \\
(\mathbf{u g} / \mathbf{m L})\end{array}$ & $\begin{array}{c}\text { Doxorubicin } \\
(\mathbf{2 5} \mathbf{~ u g} / \mathbf{m L})\end{array}$ & $\begin{array}{c}\text { Doxorubicin } \\
\mathbf{( 5 0} \mathbf{~ u g} / \mathbf{m L})\end{array}$ & $\begin{array}{c}\text { Doxorubicin } \\
\mathbf{( 1 0 0} \mathbf{~ u g} / \mathbf{m L})\end{array}$ & $\begin{array}{c}\text { Doxorubicin } \\
\mathbf{( 2 0 0} \mathbf{~ u g} / \mathbf{m L})\end{array}$ \\
\hline 1.79 & $50.7 \pm 5.54$ & $45.90 \pm 1.64$ & $45.75 \pm 2.61$ & $40.39 \pm 2.76$ \\
3.58 & $38.65 \pm 0.85$ & $37.85 \pm 1.98$ & $39.00 \pm 1.83$ & $33.83 \pm 7.60$ \\
5.37 & $36.91 \pm 0.65$ & $33.53 \pm 1.28$ & $32.64 \pm 1.19$ & $32.59 \pm 1.19$ \\
7.16 & $33.98 \pm 0.34$ & $35.02 \pm 2.83$ & $38.65 \pm 4.42$ & $35.47 \pm 2.33$ \\
\hline
\end{tabular}

*Nilai rata-rata dan Simpangan Deviasi dengan 3 kali replikasi 
Tabel V. Indek kombinasi Ko kemoterapi isolat CGs dan doxorubisin terhadap sel HeLa

\begin{tabular}{ccccc}
\hline \multirow{2}{*}{ CGs45(ug/mL) } & \multicolumn{4}{c}{ Indeks kombinasi* } \\
\cline { 2 - 5 } & $\begin{array}{c}\text { Doxorubicin } \\
\mathbf{( 2 5} \mathbf{~ u g} / \mathbf{m l})\end{array}$ & $\begin{array}{c}\text { Doxorubicin } \\
\mathbf{( 5 0} \mathbf{~ u g} / \mathbf{m L})\end{array}$ & $\begin{array}{c}\text { Doxorubicin } \\
\mathbf{( 1 0 0} \mathbf{~ u g} / \mathbf{m L})\end{array}$ & $\begin{array}{c}\text { Doxorubicin } \\
\mathbf{( 2 0 0} \mathbf{~ u g} / \mathbf{m L})\end{array}$ \\
\hline 1.79 & 0.42 & 0.35 & 0.35 & 0.29 \\
3.58 & 0.52 & 0.52 & 0.54 & 0.44 \\
5.37 & 0.74 & 0.65 & 0.63 & 0.63 \\
7.16 & 0.88 & 0.92 & 1.06 & 0.94 \\
\hline
\end{tabular}

*Combination Index, 0.1 sinergis sangat kuat, 0.1-0.3 sinergis kuat, 0.3-0.7 sinergis, 0.7-0.9 sinergis ringan-sedang, 0.9-1.1 antagonis ringan-sedang, 1.45-3.3 antagonis, > antagonis kuat-sangat kuat.
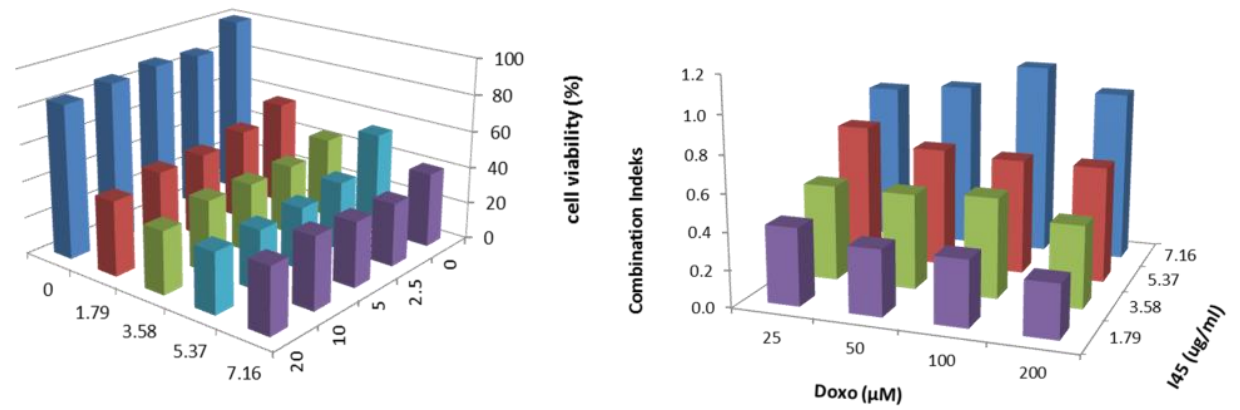

Gambar 5. pengaruh perlakuan kombinasi isolat CGs dan DOX terhadap pertumbuhan sel kanker HeLa. Perlakuan kombinasi CGs dan DOX memberikan efek sinergis kuat dan sinergis. . Sel sebanyak $10^{4}$ sel/sumuran ditanam dalam 96 well plate, diinkubasi selama 24 jam dalam media RPMI komplit tanpa atau dengan diberi perlakuan kombinasi dengan konsentrasi yang telah ditentukan. Viabilitas sel ditentukan dengan metode MTT. Hasil analisis ini merupakan representasi dari dua experiment yang berbeda, masing-masing dengan (3) replikasi.

memberikan efek sinergis kuat dan sinergis. Sel sebanyak $10^{4} \mathrm{sel} /$ sumuran ditanam dalam 96 well plate, diinkubasi selama 24 jam dalam media RPMI komplit tanpa atau dengan diberi perlakuan kombinasi dengan konsentrasi yang telah ditentukan. Viabilitas sel ditentukan dengan metode MTT. Hasil analisis ini merupakan representasi dari dua experiment yang berbeda, masing-masing dengan (3) replikasi.

\section{KESIMPULAN}

Hasil Uji kombinasi antara senyawa Glikosida cardenolid (CGs) dan doxorubisin pada dosis di bawah $\mathrm{IC}_{50}$ menunjukkan bahwa 10 dosis kombinasi memberikan efek sinergis dan satu dosis kombinasi menunjukkan efek sinergis kuat yaitu pada dosis doxorubisin $200 \mathrm{ug} / \mathrm{ml}$ dan CGs $1.79 \mathrm{ug} / \mathrm{ml}$.

\section{UCAPAN TERIMAKASIH}

Penulis mengucapkan terimakasih kepada DIKTIS Kemenag atas pembiayaan penelitian ini pada skema Hibah Integrasi Keilmuan tahun 2016.

\section{DAFTAR PUSTAKA}

American Cancer Society (2015) 'Global Cancer Facts \& Figures 3rd Edition.', American Cancer Society, (800), pp. 1-64.

Habib, M. R., Aziz, M. A. and Karim, M. R. (2010) 'Inhibition of Ehrlich's ascites carcinoma by ethyl acetate extract from the flower of Calotropis gigantea L. in mice', Journal of Applied Biomedicine, 8(1), pp. 47-54.

Habib, M. R. and Karim, M. R. (2011) 'Evaluation of antitumour activity of Calotropis gigantea L. root bark against Ehrlich ascites carcinoma in Swiss albino mice.', Asian Pacific journal of tropical medicine. Hainan Medical College, 4(10), pp. 786-90.

Mutiah R. (2014). Pengembangan Fitofarmaka antikanker "Panduan Teknik Pengembangan Obat Herbal Indonesia Menjadi Fitofarmaka. Uin Maliki Press.ISBN: 978-602-1190-265.pp 50-70

Muti, R., Griana, T. P., Ula, Q. N. and Andhyarto, Y. (2016) 'The Effect of Calotropis gigantea Leaves Extract on Fibrosarcoma Growth 
and Caspase 3 Expression .' International Journal Pharmaceutical and Clinical Research. 8(3), pp. 167-171.

Muti, R., Sukardiman, Widyawaruyanti, A. and Zulaikah, S. (2016) 'Comparison of Ethanol Extract from Roots, Leaves, and Flowers of Calotropis gigantea. Alchemy, 18, pp. 1-4.

Mutiah, R., Sukardiman, Widyawaruyanti A, (2017) 'Cytotoxic Effect Of Crude Extract And Fraction From Calotropis Gigantea Leaves On Human Colon Cancer Widr Cell Lines., International Journal Pharmacy and Pharmacetical Sciences. 9 (1), pp. 83-86.

Mutiah R. (2017). Aktivitas Dan Mekanisme Bahan Aktif Antikanker Dari Fraksi Etil Asetat Akar Calotrophis Gigantea (L.) W.T Aiton Secara In Vitro Terhadap Sel Kanker Kolon Widr. Disertasi .Fakultas Farmasi Universitas Airlangga.

Seeka, C. and Sutthivaiyakit, S. (2010). Cytotoxic cardenolides from the leaves of Calotropis gigantea.', Chemical \& pharmaceutical bulletin, 58(5), pp. 725-728.

Tacar 0, Sriamornsak P, and Dass CR. (2013). Doxorubicin: An Update on Anticancer Molecular Action, Toxicity and Novel Drug Delivery Systems. Journal of Pharmacy and Pharmacology. 65(2), pp. 157-170.

Wang, Z.-N., Wang, M.-Y., Mei, W.-L., Han, Z. and Dai, H.-F. (2008) 'A new cytotoxic pregnanone from Calotropis gigantea.', Molecules (Basel, Switzerland), 13(12), pp. 3033-3039.

Wong, S. K., Lim, Y. Y., Abdullah, N. R. and Nordin, F. J. (2011) 'Assessment of antiproliferative and antiplasmodial activities of five selected Apocynaceae species.', BMC complementary and alternative medicine. BioMed Central Ltd, 11(1), p. 3.

You, H., Lei, M., Song, W., Chen, H., Meng, Y., Guo, D. and Liu, X. (2013) 'Cytotoxic cardenolides from the root bark of Calotropis gigantea', Steroids. Elsevier Inc., 78(10), pp. 10291034. 